\title{
THE APPLICATION OF THE COOPERATIVE INTEGRATED READING AND COMPOSITION (CIRC) LEARNING MODEL IN IMPROVING THE ABILITY TO FIND ELEMENTS OF THE NONFICTION BOOK FOR CLASS VII STUDENTS OF SMP NEGERI 1 MA'U NIAS REGENCY 2020/2021 LEARNING YEAR
}

\author{
Maskaryanis \\ Telaumbanua ${ }^{1+}$ \\ Universitas \\ Fakultas Pendidikan Bahasa dan Sastra Indonesia \\ 'Email: epymend19@gmail.com.
}

Article History
Received:
Revised:
Accepted:
Published:
Keywords
Elements of non-fiction books,
Cooperative Integrated Reading and
Composition (CIRC) Learning
Model

Preface

Nowadays, the development of technology is getting faster, the easier it is for everyone to access and get information. In general, this information is in written form, both printed and digital. The human need for information is also increasing, so everyone will certainly do reading activities.

According to Tarigan (2008: 7), reading is a process that is usually carried out and used by readers to get messages, which the writer intends to convey through the media of words or written language. By reading, we will get various information conveyed by the author through the medium of words. So with reading activities, we will be able to get and understand the message directly from the author.

Reading is the process of obtaining information through writing. By reading, someone will add insight. The message conveyed by the author will be a consideration for the reader because in the discourse there is information that attracts readers. The more often you read, the more knowledgeable someone will be. Reading in education is one aspect of language skills that students need to master because reading is an important skill to support the learning process. This is because reading is the first step in understanding a subject matter. Through reading, students can absorb the information and ideas in reading. Reading in Junior High School (SMP) is a foundation for students to improve their abilities at a higher level of education. Therefore, reading needs to get serious attention from the teacher, because if the basis is not strong then at the next stage students will experience difficulties in obtaining knowledge. Relationships, deepen our perceptions or perceptions, solve the problems we face, arrange sequences for experiences. 
In the 2013 Curriculum on Indonesian subjects, one of the KI and KD studied is Core Competency 3: Understanding knowledge (factual, conceptual, and procedural) based on curiosity about science, technology, art, culture related to visible phenomena and events. eye. Basic Competency 3.15: Finding elements from fiction and non-fiction books read with the specified minimum completeness criteria (KKM), namely 75 . The indicator that must be achieved is being able to determine the elements of non-fiction books.

In this material, students carry out activities to find parts related to the elements of a non-fiction book by reading which is a form of looking for or finding something contained in a book, both its elements and the contents of the book. With regard to non-fiction books, without us realizing there are a lot of non-fiction books in our environment that we can read to broaden our knowledge of science, especially to look for the elements contained in nonfiction books.

Based on observations to students and the results of interviews with class VII Indonesian language teachers at SMP 1 Ma'u Nias, it was found that Students' ability in determining the elements of non-fiction books is still lacking. The average score of student learning outcomes, there were $25 \%$ of students who completed while $75 \%$ did not complete, even though the Minimum Completion Criteria (KKM) that students should have obtained was 75. In finding elements of nonfiction books, there are several student weaknesses including: students not able to know the cover of nonfiction books, students have not been able to determine the details of nonfiction book subsections, students have not been able to determine the title of subab in nonfiction books, students are less able to know the contents of nonfiction books, students are less able to know how to present nonfiction book content, students are less able to know the language used in non-fiction books, and students are less able to know the systematics of writing in non-fiction books.

In finding the elements of non-fiction books, another weakness is that the method used by the teacher is still unable to solve the problems faced by students in accordance with the material being studied, especially in retelling the contents of the fable.

Based on the above problems, a solution that is deemed effective is needed to improve the ability of grade VII students of SMP Negeri 1 Ma'u Nias Regency to find elements of nonfiction books, namely by using the Cooperative Integrated Reading and Composition (CIRC) learning model. According to Shoimin (2014: 51), free translation of the Cooperative Integrated Reading and Composition (CIRC) is an integrated composition of reading and writing in groups. The CIRC model is a special learning model for language subjects in order to read and find main ideas, main thoughts, or themes of a discourse.

Based on this explanation, the authors hope that reading skills using the Cooperative Integrated Reading and Composition (CIRC) learning model can help students improve learning, especially in learning to read and write, because with the Cooperative Integrated Reading and Composition (CIRC) learning model students will be required to read and writing, because this model combines writing and reading.

Based on the description above, the researchers collaborated with Indonesian language subject teachers at SMP Negeri 1 Ma'u Nias Regency to conduct scientific research. Researchers directed this research to Classroom Action Research (PTK). Researchers are interested in conducting scientific research by applying a learning model entitled: "Application of the Cooperative Integrated Reading and Composition (CIRC) Learning Model in Improving the Ability to Find Elements from the Class VII Student's Nonfiction Book of SMP Negeri 1 Ma'u Nias Regency 2020/2021 


\section{METHOD}

The type of research to be carried out is classroom action research (PTK). It is said that PTK is because this research aims to improve the learning process about non-fiction books in class VII SMP Negeri 1 Ma'u Nias. This is in accordance with the opinion Wardhani (2010: 115) said, "Classroom Action Research is research conducted by teachers in their own class through self-reflection with the aim of improving their performance so that student learning outcomes increase".

Furthermore, Arikunto (2006: 3) states that: "Classroom action research is a reflection of learning activities in the form of an action, which is deliberately raised and occurs in a class together. This classroom action research is carried out to improve the quality and learning process that takes place in the classroom in the form of a cycle. According to Asmani (2011:37) argues "Classroom action research is a study that is carried out systematically and reflective of various actions taken by teachers who are also researchers".

Based on the above opinion, the writer concludes that Classroom Action Research is research conducted by teachers in their class on learning activities in the form of an action to improve student learning outcomes.

The type of action studied (the object of action) in this study was to improve the ability to find elements of non-fiction books for class VII-B students of SMP Negeri 1 Ma'u Nias Regency 2020/2021 Learning Year.

In conducting research, there are four types of activities that must be carried out in classroom action research, namely planning, implementing, observing, and reflecting. There are several procedures for conducting this research, including: Planning Stage

In the initial stage of this research, the researcher conducted a discussion with the Indonesian language teacher in class VII-B about the implementation of action research to improve the ability to find elements of non-fiction books for students. Therefore, in accordance with the existing problems, the researcher and the teacher formulate a plan to solve the problems encountered in learning to find the elements of non-fiction books.

The steps that will be carried out include the following. First, reading and understanding the Indonesian curriculum for grade VII even semester. Second, determine core competencies, select basic competencies, set indicators and select materials in accordance with the research title. Third, prepare the necessary facilities and infrastructure. Fourth, prepare observation instruments to monitor teacher and student activities. Fifth, contact the parties needed for the implementation of classroom action research. Sixth, determine the implementation time.

2. Implementation Stage

This stage is the implementation stage of the learning plan that has been made. At this stage the researcher acts as an implementer and the teacher acts as an observer of the action. Actions that include the process of teaching and learning activities in improving students' abilities to find elements of non-fiction books through the Cooperative Integrated Reading and Composition (CIRC) learning model, meaning that the teacher delivers in front of the class reading learning material.

To assess the activities carried out by students to find the elements of the non-fiction book, the assessment aspects below are used. 
IJEMS: Indonesian Journal of Education and Mathematical Science

2021 Vol. 1, No. 1, pp. 11-18

$\operatorname{ISSN}(e): 2715-985 x$

DOI: https://doi.org/10.30596/ijems.v1i3.2602

(C)2020IJEMS@UMSU.All Rights Reserved.

RUBLIC FOR ASSESSMENT OF THE ABILITY OF FINDING NONFICTIONAL BOOK INGREDIENTS

\begin{tabular}{|c|l|c|c|c|c|}
\hline \multirow{2}{*}{ No } & \multicolumn{3}{|c|}{} & \multicolumn{3}{l}{} \\
\cline { 3 - 6 } & & \multicolumn{3}{|l|}{ Score } \\
\cline { 3 - 6 } & & $\mathbf{1}$ & $\mathbf{2}$ & $\mathbf{3}$ & $\mathbf{4}$ \\
\hline 1 & Book Cover & & & & \\
\hline 2 & Details of Sub chapter Book & & & & \\
\hline 3 & Ways to Present Books & & & & \\
\hline 4 & Title of Section & & & & \\
\hline 5 & Book Contents & & & & \\
\hline 6 & Languages Spoken & & & & \\
\hline 7 & Writing Systematics & & & & \\
\hline
\end{tabular}

Score Description

Source: Kusmayadi (2017: 64-65)

$4=$ Very complete and clear

$3=$ Good and clear

$2=$ Good enough and clear

$1=$ Not good and unclear

Maximum score $=8$

Final score: The total score obtained X 100

Maximum score

Furthermore, determining the minimum threshold for passing and assessing certain values can be done by calculating the percentage of determining the value or calculating the percentage for a scale of 1-4. Look at the following table.

Table 2

INTERVAL ASSESSMENT

\begin{tabular}{|c|c|c|c|}
\hline $\begin{array}{c}\text { Mastery Level } \\
\text { Percentage Interval }\end{array}$ & \multicolumn{2}{|c|}{ Change Value Scale Four } & \multirow{2}{*}{ Information } \\
\cline { 2 - 3 } & $\mathbf{1 - 4}$ & D-A & \\
\hline $86-100$ & 4 & A & Very good \\
\hline $76-85$ & 3 & B & Good \\
\hline $56-74$ & 2 & C & Enough \\
\hline $10-55$ & 1 & D & less \\
\hline
\end{tabular}

Sumber: Nurgiyantoro (2010:253)

Interval Percentage Level of Mastery Change Value Scale Four Information

1-4 D-A

86-100 4 A Very Good

76-85 3 B Good

56-74 2 C Enough

10-55 1 D Less 
Source: Nurgiyantoro (2010: 253)

d. Looking for an average

Djamarah (2010: 306) said, "In analyzing the existing data, researchers classify the percentage of all percent." Researchers used the formula to find the average, namely:

$$
\begin{aligned}
\mathrm{M}= & \text { Mean (Average value) } \\
\sum X= & \text { The sum of the total values obtained from the sum of the } \\
& \text { scores for each individual } \\
N & =\text { he number of individuals }
\end{aligned}
$$

Information:

$\mathrm{M}=$ Mean (average value)

$\sum X=$ The total value obtained from the sum of the scores for each individual

$\mathrm{N}=$ Number of individuals

2. Qualitative Data Analysis

After analyzing quantitative data, researchers analyzed qualitative data sourced from the observation sheet by taking the following steps:

a. Data reduction, namely selecting and classifying data based on information and organized according to the researcher's questions.

b. Data exposure, namely that data that has been organized are grouped or described to meaningful means in the form of tables or graphs or in narration.

c. The conclusion, namely that based on the explanation that has been made, a conclusion is drawn in the form of a short statement / formula.

After obtaining valid data from the observation sheet, the researcher will analyze and evaluate the data using the formula proposed by Tuckman in Nurgiyantoro (2010: 287) as follows:

Information:

$$
\mathrm{TP}(\%)=\frac{\mathrm{F}}{\mathrm{KA}} \times 100
$$

TP: percentage level

$\mathrm{F}$ : frequency of research and student activity

KA: total number of research and student activity

100: maximum percentage.

\section{RESULTS AND DISCUSSION \\ Research Result}

This classroom action research was conducted at SMP Negeri 1 Ma'u, Niasyang Regency, having the address at lasarasiwalubanua kecamatan Ma'u Kabupaten Nias. In SMP Negeri 1 Ma'u, Niaster Regency there are 7 rooms as a place to study. Class VII two classes, class VIII two classes, and Class IX three classes. The research subjects were students of class VII-B in Semester II (two), the 2020/2021 Learning Year, totaling 20 people, namely 9 boys and 11 girls.

Before starting research activities, first consulted the Principal of SMP Negeri 1 Ma'u Nias Regency, namely Torosokhi Waruwu, S.Pd.

After obtaining approval and permission from the principal to carry out the research, the researchers consulted with subject teachers to determine a schedule for research activities in class VII-B according to the roster of teaching and learning activities at SMP Negeri 1 
Ma'u Nias Regency Even Semester for the 2020/2021 Learning Year. Indonesian language subject 6 hours of lessons per week with two meetings, namely in class VII-B: Monday and Tuesday.

In the implementation of this research, observers were present to observe the performance of researchers and student activities during teaching and learning activities in accordance with the observation sheets provided by the researcher. The implementation of this research was carried out with the following procedure.

\section{a. Planning}

At this stage, the researcher prepares a syllabus for one basic competency, prepares lesson plans, prepares material to determine the elements of a non-fiction book, attendance list, observation sheet, field notes and evaluation sheets.

b. Action

At this stage, the researcher carried out the whole process of teaching and learning activities with the material of conveying opinions in the discussion through the Cooperative Integrated Reading and Composition (CIRC) learning model as that had been compiled in the learning implementation plan for each cycle. Apart from carrying out the teaching and learning process, evaluation is also carried out at the end of the cycle.

c. Observation

At this stage, the researcher carries out simultaneously the learning process which includes all student activities during learning activities, as well as increasing the student's ability to determine the elements of non-fiction books through the Cooperative Integrated Reading and Composition (CIRC) learning model in Indonesian subjects.

d. Reflection

At this stage, the researcher carries out the analysis of the learning outcomes as well as prepares a plan for improvement for the next cycle, if indicators of successful research implementation have not been achieved and if they have been achieved, research findings are formulated.

Research Implementation to Improve the Ability of Class VII Students of SMP Negeri 1 Ma'u Nias Regency Determining the Elements of a Non-Fiction Book by Applying the Cooperative Integrated Reading and Composition (CIRC) Learning Model.

1. Has not succeeded in improving students' reading skills, especially in determining the elements of non-fiction books using the CIRC learning model.

2. Researchers are too focused on the results to be achieved so that they pay less attention to the learning process.

3. The delivery of the CIRC learning model to students was not optimal because researchers were too hasty in explaining the learning material.

Based on the results of student activity in the first cycle, the percent average value at the first meeting $=54.44 \%$ and the second meeting $=69.44 \%$, this can be seen in the graph below:

AVERAGE VALUE OF STUDENT ACTIVITY IN CYCLE I 


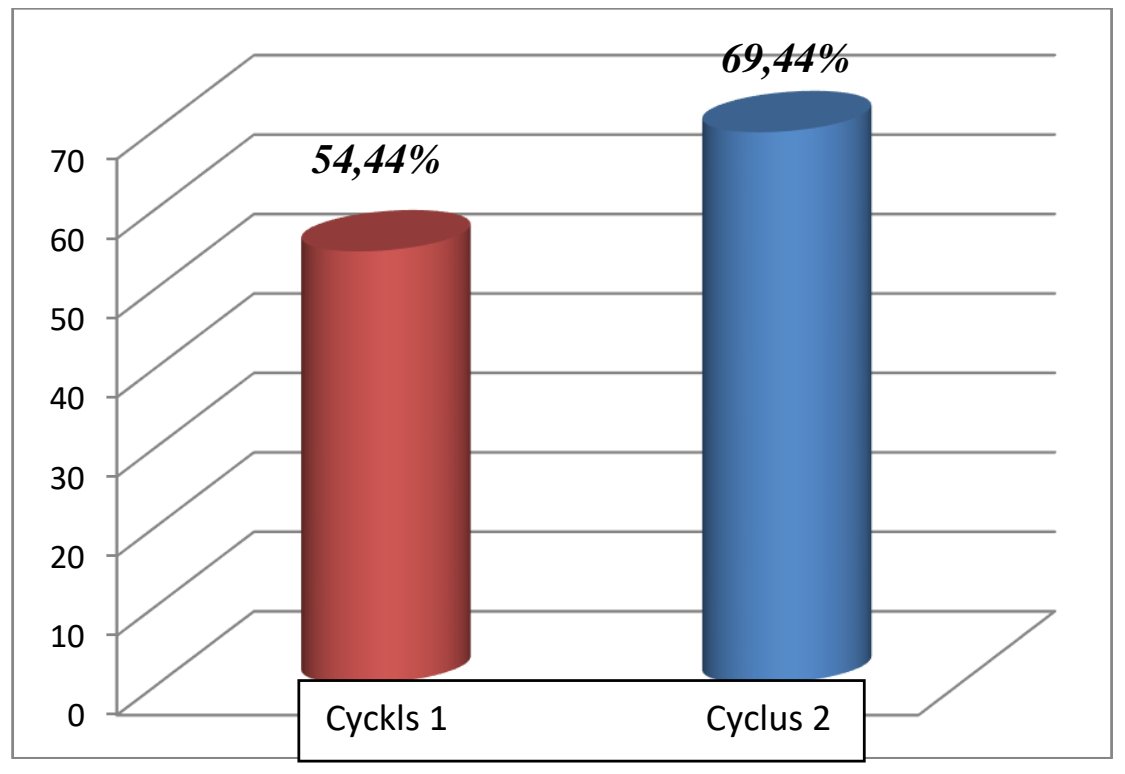

Graph 1: The average value of student activity in cycle I

Information: Meeting I $=54.44 \%$

Meeting II $=69.44 \%$

d) Reflection

Based on the weaknesses obtained in cycle I, the researcher held a reflection with the aim of improving at the next meeting, including:

1. Researchers should review learning so that they find solutions and can improve learning outcomes, especially in determining the elements of non-fiction books.

2. Researchers should not focus too much on learning outcomes but the learning process is the most important so that students can understand learning well.

3. Researchers should carry out the next lesson to improve these weaknesses.

3) Analysis of Evaluation Results

Based on the results in cycle I, the researcher conducted an analysis of student learning outcomes, namely:

a. Result of Analysis of Spiritual Attitude Assessment (KI-1) Cycle I

The assessment of spiritual attitudes consists of 4 aspects, namely: praying before and after carrying out activities, giving thanks for the gift of God Almighty, being grateful when they succeed in doing something, and respecting others who carry out worship according to their religion.

This assessment was carried out in the first cycle of spiritual value obtained an average value of $74.75 \%$ with the predicate "Enough". It consists of the predicate very good $=6$ people $(30 \%)$, good $=7$ people $(35 \%)$, enough $=3$ people $(15 \%)$ and less $=4$ people $(20 \%)$. To make it easier it can be seen in the following graph:

RESULTS OF SPRITUAL ATTITUDE (KI-1) CYCLE I

Grafik 2 : Penilaian Sikap Spritual (KI-1)Siklus I 
IJEMS: Indonesian Journal of Education and Mathematical Science

2021 Vol. 1, No. 1, pp. 11-18

$\operatorname{ISSN}(e): 2715-985 x$

DOI: https://doi.org/10.30596/ijems.v1i3.2602

(C)2020IJEMS@UMSU.All Rights Reserved.

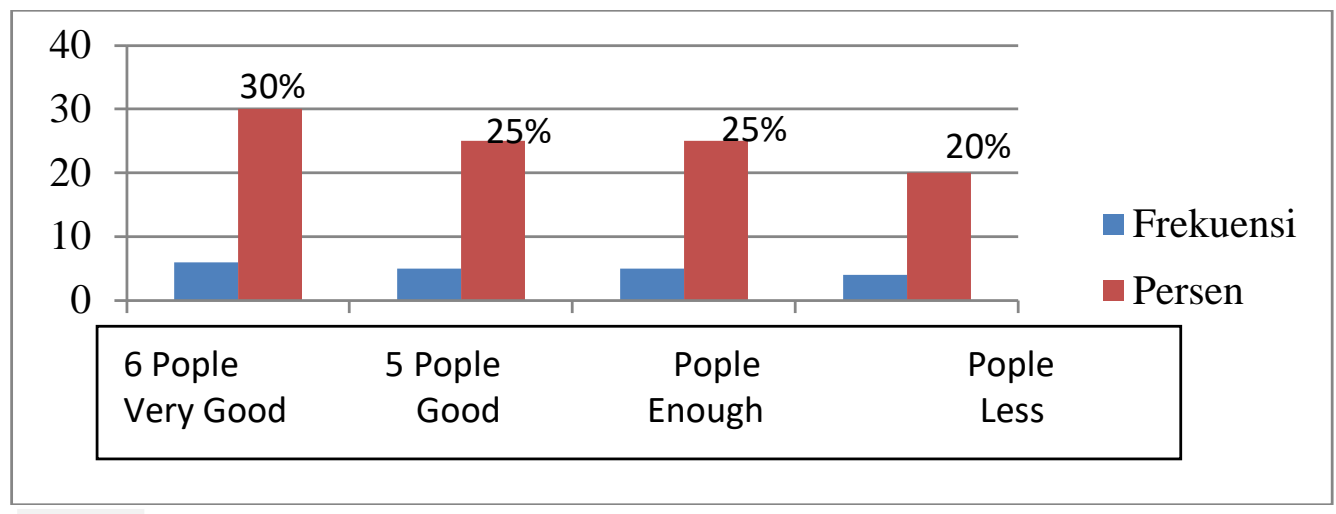

requency:

- Often pray before and after doing activities there are 6 people.

- Often pray before and after doing activities there are 5 people.

- Sometimes praying before and after doing activities there are 5 people.

- Often pray before and after doing activities there are 4 people.

Percent:

- Very good $=30 \%$

- Good $=25 \%$

- Enough $=25 \%$

- Less $=20 \%$

The results of the analysis of the value of social attitudes obtained an average value of $70.65 \%$ with the predicate "Enough" (attachment 20 table 13). It consists of the predicate "Very Good" $=1$ person $(5 \%)$; Good $=4$ people $(60 \%)$; Enough $=13$ people $(25 \%)$; and Less $=2$ people $(10 \%)$. To make it easier it can be seen in the following graph:

RESULTS OF SOCIAL ATTITUDE ASSESSMENT (KI-2) CYCLE I

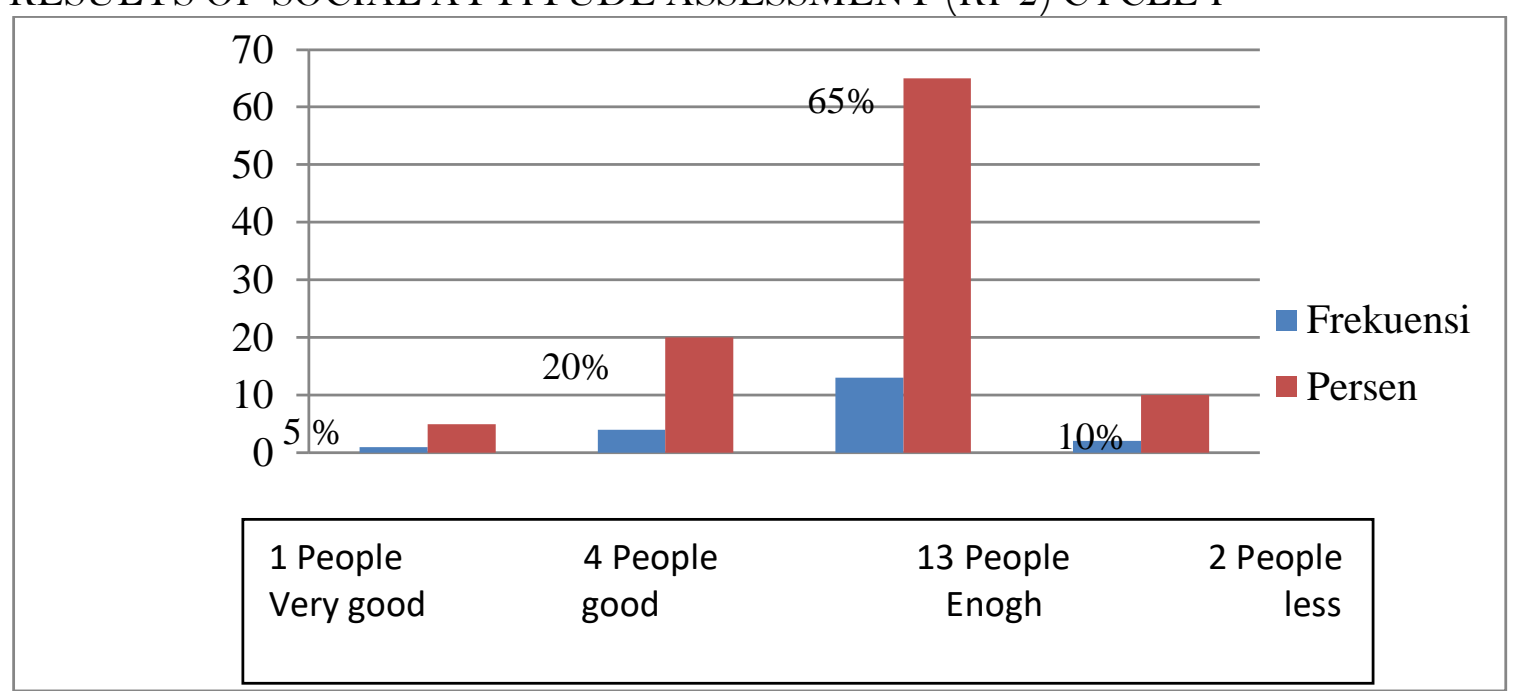

Information:

Frequency:

- Often honest, discipline, responsibility, tolerance, mutual cooperation, courteous and confident there is 1 person.

- Often honest, discipline, responsibility, tolerance, mutual cooperation, courteous and confident. There are 4 people.

- Sometimes there are 13 people honest, discipline, responsibility, tolerance, mutual 
IJEMS: Indonesian Journal of Education and Mathematical Science

2021 Vol. 1, No. 1, pp. 11-18

$\operatorname{ISSN}(e): 2715-985 x$

DOI: https://doi.org/10.30596/ijems.v1i3.2602

(C)2020IJEMS@UMSU.All Rights Reserved.

cooperation, polite and confident.

- Sometimes honest, discipline, responsibility, tolerance, mutual cooperation, courtesy and confidence there are 2 people.

\section{Percent:}

- Very good $=5 \%$

- Good $=20 \%$

- Enough $=65 \%$

- Less $=10 \%$

Table 3

Student Mastery Level Determining the Elements of Nonfiction Books Through the Cooperative Integrated Reading and Composition (CIRC) Learning Model Cycle I

\begin{tabular}{|l|l|l|l|l|}
\hline $\begin{array}{l}\text { Percentage } \\
\text { Interval }\end{array}$ & $\begin{array}{l}\text { Change } \\
\text { Value } \\
\text { Scale of } \\
\text { Ten }\end{array}$ & information & $\begin{array}{l}\text { he } \\
\text { amount } \\
\text { that } \\
\text { students } \\
\text { earn }\end{array}$ & Persen\% \\
\hline $86-100$ & 4 & A (Very well) & - & - \\
\hline $76-85$ & 3 & B (good) & 2 people & $10 \%$ \\
\hline $56-75$ & 2 & C (enough) & 15 people & $75 \%$ \\
\hline $10-55$ & 1 & (less) & 3 people & $15 \%$ \\
\hline Jumlah & & 20 people & $\mathbf{1 0 0 \%}$ \\
\hline
\end{tabular}

From the table above, a graph can be made of students' ability levels to determine the elements of nonfiction books through the Cooperative Integrated Reading and Composition (CIRC) learning model in cycle I. To make it easier it can be seen in the following graph:

ASSESSMENT RESULT OF KNOWLEDGE TEST (KI-3) CYCLE I

Graph 4: Knowledge Test Assessment (KI-3) Cycle I

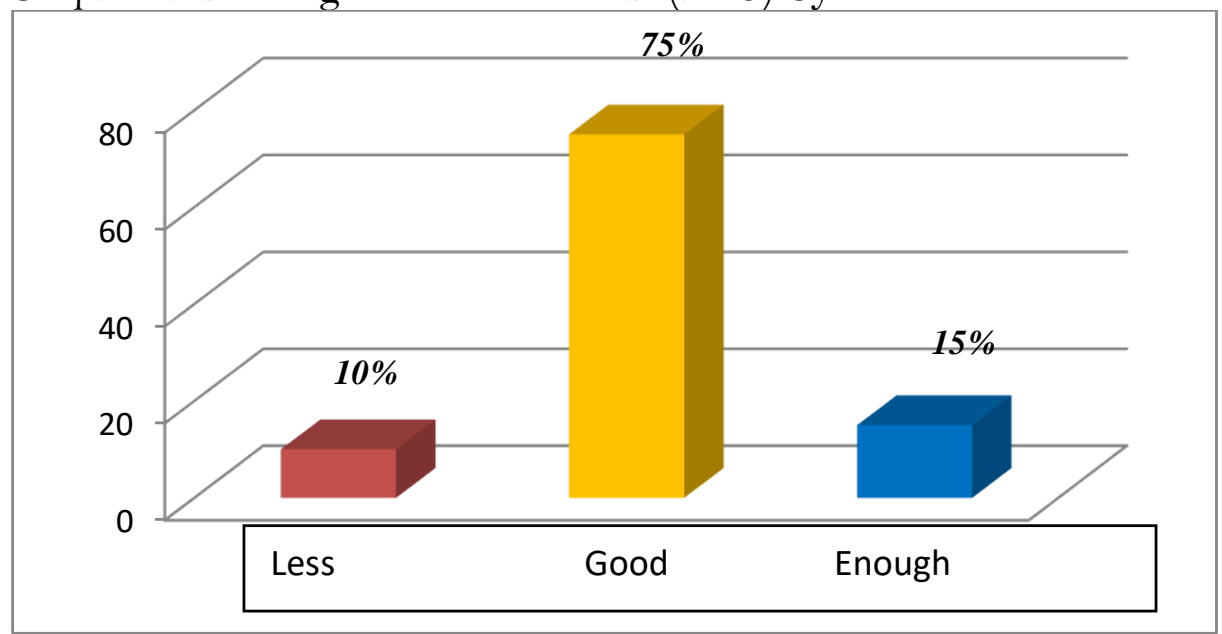

Information:
1) Good $=10 \%$
2) Enough $=75 \%$
3) Less $=15 \%$

Implementation of the learning process 
The implementation of the teaching and learning process on the subject matter found elements of nonfiction books through the Cooperative Integrated Reading and Composition (CIRC) learning model, which increased at the second meeting with an average value of $95.23 \%$. Based on these results, there are several strengths and weaknesses of researchers in the second cycle of the second meeting.

(a) The strengths of the researcher are: after the researcher applies the Cooperative Integrated Reading and Composition (CIRC) learning model to the test to find elements of non-fiction books, the results obtained are an average of 86.8 and the researcher has succeeded in motivating students towards learning so that student activity can increase.

(b) The weakness of the researcher based on the observation sheet has not addressed the learning plan and has not concluded the learning material as a whole.

Based on the results of student activity in the second cycle, the percent average value at the first meeting $=81.11 \%$, and the second meeting $=90.55 \%$. This can be seen in the following graph:

AVERAGE VALUE OF II STUDENT ACTIVITY

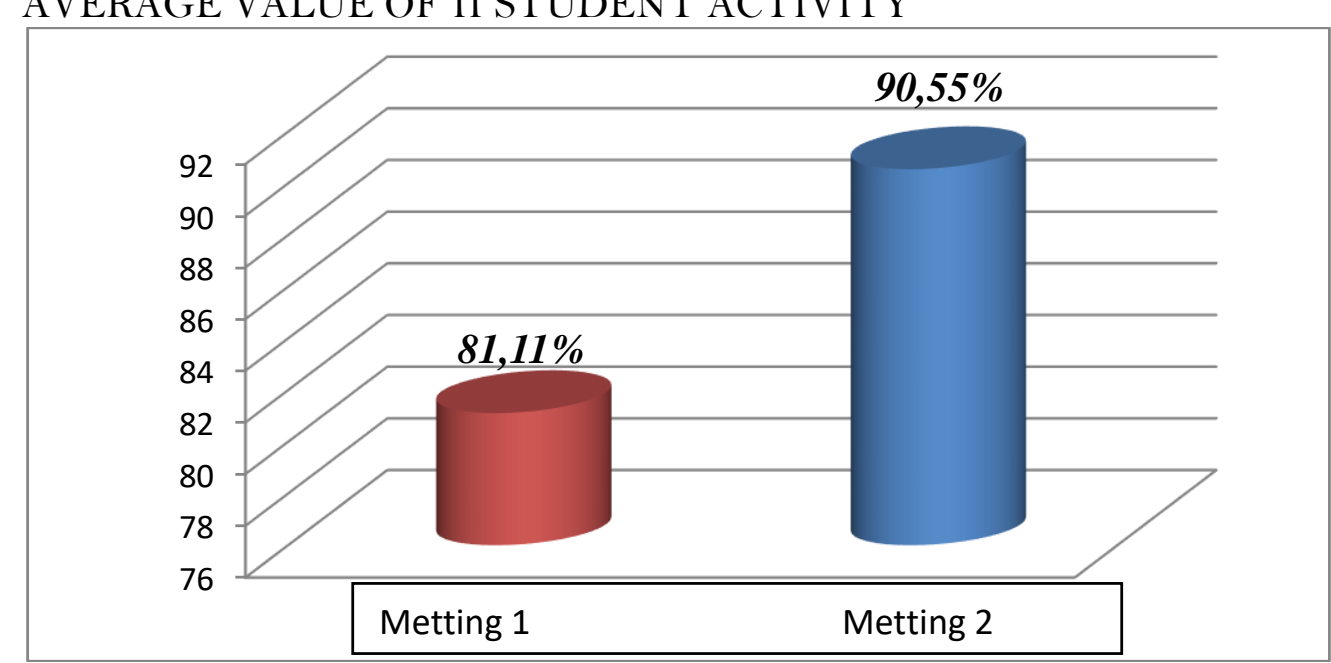

Graph 5: The average value of cycle II student activities

Information: Meeting $1=81.11 \%$

Meeting $2=90.55 \%$

The results of the analysis of the value of social attitudes obtained an average value of $82.6 \%$ with the predicate "good". It consisted of the predicate "very good" = 6 people $(30 \%)$; good = 13 people $(65 \%$; enough $=1$ person $(5 \%)$; and less $=$ none. For convenience, it can be seen in the following graph:

RESULTS OF SOCIAL ATTITUDE ASSESSMENT (KI-2) CYCLE II 


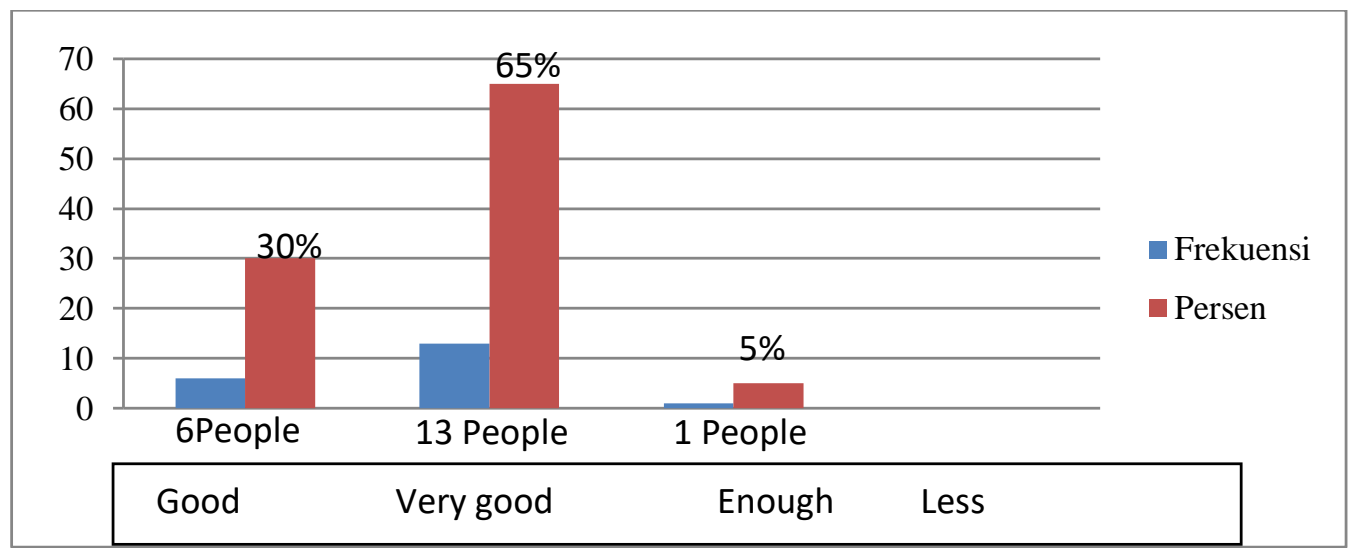

Graph 7: Assessment of Social Attitudes (KI-2) Cycle II

Information:

Frequency:

1) Often honest, discipline, responsibility, tolerance, mutual cooperation, courteous and confident, there are 6 people.

2) Often honest, discipline, responsibility, tolerance, mutual cooperation, polite and selfconfident, there are 13 people.

3) Sometimes honest, discipline, responsibility, tolerance, mutual cooperation, courtesy and confidence there is 1 person.

4) Sometimes there are 0 people honest, discipline, responsibility, tolerance, mutual cooperation, polite and self-confidence.

Percent:

1) Very good $=30 \%$

2) Good $=65 \%$

3) Enough $=5 \%$

4) Less $=0 \%$

\section{CLOSING}

\section{Conclusion}

Based on the results of this study, the authors conclude in accordance with the findings of the research that has been done are as follows:

1. In Cycle I, the results of the value increase in the ability to find elements from nonfiction books read through the Cooperative Integrated Reading and Composition (CIRC) learning model, namely: 65.05 predicate (enough). The value of knowledge in the second cycle the average value $=86.86$ predicate (Very Good) .

2. In Cycle I, the results of student activities in participating in the learning process through the Cooperative Integrated Reading and Composition (CIRC) learning model increased because through this learning it involved students actively participating in teaching and learning activities. This is in accordance with the observation data of student activity in the first cycle $=$ an average of $61.94 \%$ predicate (Enough), and the second cycle $=$ an average of $85.83 \%$ predicate (Good).

3. The value of spiritual attitudes in the learning process in the first cycle the average value $=74.75$, predicate (sufficient) and in the second cycle increased, with an average value $=85.48$ predicate (good). The value of social attitudes in the first cycle with an average value $=70.65$ predicate (enough) and in the second cycle increased, with an average value $=82$ predicate $(\mathrm{good})$. 
4. Using the Cooperative Integrated Reading and Composition (CIRC) learning model can improve students' ability to find elements of nonfiction books in class VII-B of SMP Negeri 1 Ma'u Nias Regency 2020/2021 Learning Year.

\section{Suggestion}

Based on the results of the research that has been done, the suggestions that can be given are:

1. This research is expected to be used by Indonesian language subject teachers at SMP Negeri 1 Ma'u Kabupaten Nias

2. As input for students of SMP Negeri 1 Ma'u Nias Regency that the Cooperative Integrated Reading and Composition (CIRC) learning model can motivate and assist students in learning activities, especially in finding elements from nonfiction books.

3. It is hoped that the next researcher can apply the Cooperative Integrated Reading and Composition (CIRC) learning model to be even better, including in designing and modifying learning models to really improve the learning process.

\section{References}

Arikunto, 2006. Classroom Action Research, PT Bumi Aksara, Jakarta.

Artati, Budi, 2007, Loves to Read and Write, CV Synergy Pustaka Applied Competencies, Yogyakarta.

Asmani, Jamal Ma'mur, 201 1, Classroom Action Research, Laksana, Jogjakarta.

Budiyanto, Agus Krisno, 2016, Syntax 45 Learning Models in Student Centered Learning (SCL), Muhammadiyah University, Malang.

Dalman, 2013, Reading Skills, PT Raja Grafindo Persada, Jakarta.

Djamarah, Syaiful Bahri and Zain, Aswan, 2010: 306, Teaching and Learning Strategies, PT. Asdi Mahasatsya.

Huda, Miftahul, 2013, Teaching and Learning Models, Student Library, Yogyakarta.

Istarani, 2011, 58 Innovative Learning Models, Persada Media, Medan.

Ministry of Culture. 2016. Indonesian Language. Jakarta: Ministry of Education and Culture. Kusmayadi, Ismail, 2017, Material Summary Book and Brilliant Indonesian Language

Exercises, Grafindo Media Pratama, Bandung.

Kosasih, 2017, Bahasa Indonesia, Jakarta: Ministry of Education and Culture.

Mulyati, Yeti, 2015, Indonesian Language Skills Elementary School, Open University, South

Tangerang.

Nurgiyantoro, Burhan, 2005, Children's Literature An Introduction to Children's World

Understanding, Gadjah Mada University Press, Yogyakarta.

Nurgiyantoro, Burhan, 2010, Assessment of Indonesian Language Learning, BFFE,

Yogyakarta.

Nurhadi, 2016, Reading Technique, PT Bumi Aksara, Jakarta.

Purwanto, 2009, Evaluation of Learning Outcomes, Learning Library, Surakarta.

Shoimin, Aris, 2014, 68 Innovative Learning Models in the 2013 Curriculum, Ar-Ruzz Media, Yogyakarta.

Somadayo, Samsu, 2011, Reading Learning Strategies and Techniques, Graha Ilmu, Yogyakarta.

Tarigan, Henry Guntur, 2008, Reading as a Language Skill, Space, Bandung.

Wardhani, 2010, Class Action Research, Open University, Jakarta. 